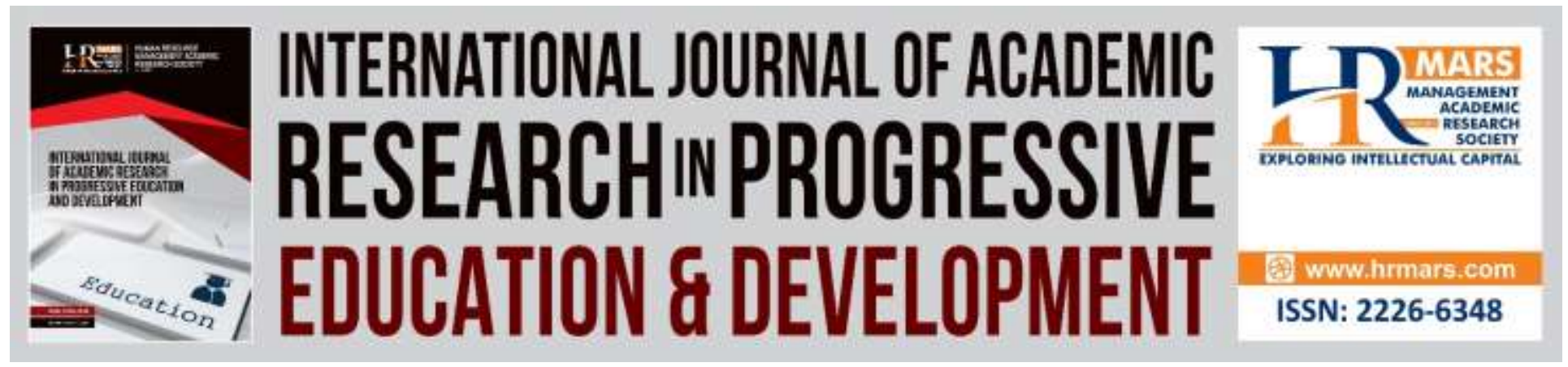

\title{
The Effects of Smartphone Usage on University Students
}

\author{
Nalini Arumugam, Sivajothy Selvanayagam, Sai Tarishini Sathiyasenan
}

To Link this Article: http://dx.doi.org/10.6007/IJARPED/v9-i3/7960

DOI:10.6007/IJARPED/v9-i3/7960

Received: 10 July 2020, Revised: 15 August 2020, Accepted: 28 August 2020

Published Online: 24 September 2020

In-Text Citation: (Arumugam et al., 2020)

To Cite this Article: Arumugam, N., Selvanayagam, S., \& Sathiyasenan, S. T. (2020). The Effects of Smartphone Usage on University Students. International Journal of Academic Research in Progressive Education and Development, 9(3), 170-183.

\section{Copyright: (C) 2020 The Author(s)}

Published by Human Resource Management Academic Research Society (www.hrmars.com)

This article is published under the Creative Commons Attribution (CC BY 4.0) license. Anyone may reproduce, distribute, translate and create derivative works of this article (for both commercial and non-commercial purposes), subject to full attribution to the original publication and authors. The full terms of this license may be seen at: http://creativecommons.org/licences/by/4.0/legalcode

\section{Vol. 9(3) 2020, Pg. 170 - 183}

Full Terms \& Conditions of access and use can be found at http://hrmars.com/index.php/pages/detail/publication-ethics 


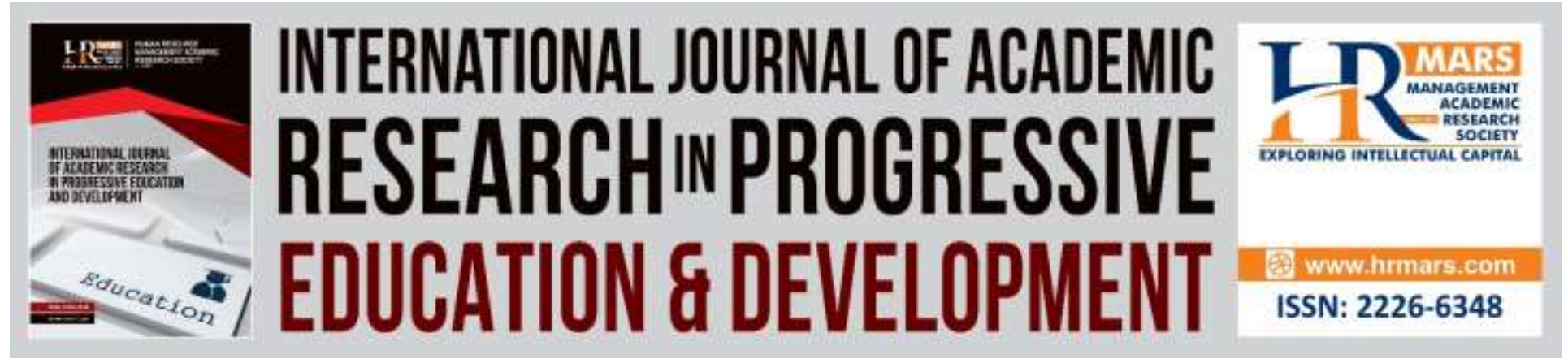

\title{
The Effects of Smartphone Usage on University Students
}

\author{
Nalini Arumugam ${ }^{1}$, Sivajothy Selvanayagam ${ }^{1}$, Sai Tarishini \\ Sathiyasenan ${ }^{2}$ \\ ${ }^{1}$ Akademi Pengajian Bahasa, Universiti Teknologi MARA, Shah Alam, Malaysia, ${ }^{2}$ Faculty of \\ Health Sciences, Universiti Kebangsaan Malaysia \\ Email: sivajothy@uitm.edu.my
}

\begin{abstract}
This study examined the daily usage of smartphones by university students. The study utilised a questionnaire via Google form to elicit information from 106 tertiary level students that had agreed to participate in the research. The data obtained from the survey was compiled into tables to categorize the respondents into hours they had spent using their smartphones. A descriptive quantitative analysis was used to examine the findings in the study. Results indicate that too much time spent on smartphones late night affects students' quality of sleep, which in turn affects students' state of mind in the next day. In addition, it was found that students in the 1830 age range are the ones most affected in their social interactions because of the reliance on smartphones. Findings also indicated that university students' excessive smartphone use during the night has negative effects on their well-being. They are unable to concentrate during lectures the following day, often feeling sleepy during the day, and face difficulties handling the day to day pressures, as well as, thinking rationally whenever problems occur. In addition, results also revealed that when university students rely too much on their mobile phones, they become anxious when their gadgets are not with them. In short, students' dependency on their smartphones affects them both physically and psychologically.
\end{abstract}

Keywords: Smartphone, Physical, Psychological, Addiction, Sleep Deprivation

\section{Introduction}

Miller (2017) acclaimed that the current greater usage of smart phone is bringing much of our lives online, such as interacting via texts and on social media instead of face to face human contact. There are many interesting things that we can do with the smartphone, for instance interacting with individuals that live miles away, getting latest updates from online websites and -social media. The smartphone technology really eases our agenda to keep everyone connected with friends and family. However, Short and Louca (2015) opined that smartphones distract focus on real life. They added that using the smartphone or a tablet at bedtime may cause harm 
to our health especially if we do not get sufficient sleep during the night. $63 \%$ of smart phone users age 18-29 fall asleep with a cell phone, smartphone or tablet in bed (Leonard, 2015). The LED lights of electronic screens suppress our melatonin levels in the body, making it harder to fall asleep when we have spent the evening gazing at the screen (Miller, 2017).

Miller (2017) and Sarhandi et al. (2017) indicated that the more time spent on looking at the electronic screen, the harder it is to fall asleep. This leads to sleep deprivation as well as poor sleep quality, which can cause emotional disturbance, decrease alertness, excessive daytime sleepiness and impair memory and cognitive processing (Giri et al., 2013). Sleep deprivation also weakens the ability of the part of the brain that handles reasoning, known as the prefrontal cortex. When this part of the cortex is impaired, sleep deprived individuals display unhealthy emotions, which in turn affects the amygdale negatively, that causes abnormal processing of emotion (Davis, 2018).

\section{Background of the Study}

University students rely mostly on their electronic devices, mainly smartphones to keep them organized and informed. The features that are constantly used by them include the calendar, alarm and camera to take pictures of their notes. Russel (2018) shared that his study indicated that his respondents see the smartphone as an essential device for them to keep up with their activities, such as homework and assignments. The portability and accessibility of the smartphone make it possible for students to use it anywhere and anytime when they need to gather facts or information (Arumugam, et al., 2019; Deloitte Global Consumer Survey, 2016). Akpan and Abe (2017) claimed that the smartphone is an effective learning resource for the teacher and the learner as they have the entire globe in their hands, enabling them to gain access to unlimited information, life pictures/ videos etc. Jafarzadeh-Kenarsari et al. (2018) too perceived that the smartphone is a resourceful technology to provide the latest information. With the existence of the Internet, the smartphone has become a major tool in society to stay connected with each other. Students often use their smartphones for educational purposes (Arumugam, et al. 2019; Tariq, 2013). However, Wilmer, Sherman and Chein, (2017) shared from his research that all students who have smartphones used them for about 4 to 10 hours. Shockingly, some students spend more than 10 hours a day on their smartphone and most of them use it during class time. This affected his respondents' academic performance, he added. Lepp et al. (2015) reported that students who used the cell phone more on a daily basis were likely to have a lower GPA than students who used it less. Basing their conclusions on a sample of 536 undergraduates from 82 self-reported undergraduates at a large public university, the researchers suggested a vital need to sensitize students and educators about the potential academic risks associated with high cell phone usage.

Babak (2016) stated that sleep is crucial component for physical function and solid cognitive processing. Sleep has the most important role in our daily life and proper sleep is of utmost importance for the well-being children and adolescents. Lack of sleep affects almost every type of tissue and system in the body - from the brain, heart, and lungs to metabolism, immune function, mood, and disease resistance. Research shows that chronic lack of sleep or getting poor quality sleep constantly increases the risk of health complications including high blood pressure, cardiovascular disease, diabetes, depression, and obesity (National Institute of Neurological 
Disorders and Stroke, 2018). Sleep deprivation is not a new phenomenon, and it happens when an individual gets less sleep than he or she needs to feel awake and alert in the morning. Some people such as older adults seem to be more resistant to the effects of sleep deprivation, while others, especially children and young adults are more vulnerable (FNP, 2018). Nasirudeen et al. (2017) too found that about 50\% of participants reported sleeping 6 hours or less because of their addiction to social networking sites and this could become a be risk a factor for sleep disorder issues and poor academic performance.

Acharya et al. (2013) discovered that addiction or excessive smartphone usage affects users' health. They found that headaches were the most common symptom $(51.47 \%)$ followed by irritability/anger (50.79\%). They also shared some common mental symptoms such as lack of concentration on given tasks, low academic performance, insomnia and anxiety. Gutiérrez et al. (2016) emphasised that smartphone addiction is detrimental to the individual both physically and psychologically. They found sleep deprivation anxiety, stress, and depression are associated with smartphone usage. Whenever a habit is converted into an obligation, it becomes an addiction (Alavi et al., 2012). Gutiérrez et al. (2016) suggested that Internet addiction is similar to drug addiction except it does not involve a substance abuse.

Parasuraman et al., (2017) conducted an online study on 409 Malaysians and postulated that excessive smartphone usage may lead to physiological and psychological complications. They added that if addition to smartphone usage continues, they will undergo the same results as alcohol addiction (Alavi et al., 2012). Another study by Augner and Hacker (2012) exposed that there is an association between over usage of smartphones and psychological health. They pointed out that low emotional stability, chronic stress, and depression have a correlation with excessive smartphone usage. Cha and Seo (2018) investigated the predictive factors of smartphone addiction in middle school students in South Korea. The researchers revealed that teenagers who spend more that 4 hours on their electronic gadgets have a higher risk of committing suicide. There are two school of thoughts; the smartphone is a beneficial device while the other perceive the smartphone to be detrimental to students' health. Thus, this divide makes the study crucial to be carried out among tertiary level undergraduates in Malaysia.

\section{Statement of Problem}

Malaysian Healthcare Performance (2017) conducted a survey involving mobile phone addiction among Malaysians. The survey revealed that $95 \%$ of the survey participants were using smartphones. The results showed that $64.3 \%$ of the participants in the study used their mobile phones for approximately an hour and remaining participants used it for more than an hour. Nearly $36.7 \%$ of the study participants had the habit of checking their mobile phones for updates in between sleep, while $27.1 \%$ felt it was not convenient for them to check their mobile phones often.

Based on Deloitte Global Mobile Consumer Survey (2016) the average American looks at his or her Smartphone 47 times per day. Among 18-24-year-olds, that figure rises to 87, so the trend is only going one way. The obsession is further illustrated by the fact that $40 \%$ check their devices within five minutes of waking up and $30 \%$ within five minutes of going to sleep. Even in the middle of the night, $50 \%$ of Americans wake up to check their smartphone text messages. 
Moreover, according to Hospital Management and Health Policy (Ministry of Health Malaysia, 2016) sleep disturbances among health workers using WhatsApp in Malaysia was relatively high. In multivariate analyses, respondents aged 30 years or younger and those being anxious when denied access to "WhatsApp" activities had significantly higher odds of experiencing poor sleep quality and excessive daytime sleepiness. Women had significantly higher odds of experiencing poor sleep quality than men. Respondents who were heavily involved on WhatsApp at night experienced significantly higher odds of excessive daytime sleepiness as compared to those who did not use their phones before falling asleep. The prevalence of subjective poor sleep quality was $86.8 \%$ while the prevalence of excessive daytime sleepiness was $80.7 \%$. FNP (2018) and Nasirudeen et al. (2017) indicated that the negative consequences associated with a lack of sleep including exhaustion and inattentiveness to tasks the following day. However, there is no further research about how mobile phone usage affects sleeping patterns of young adults.

Therefore, the objectives of this research are as follows:

- to examine the impact of smartphone usage on the quality of sleep among undergraduates

- to discover the effects of late night usage of smartphones to their mental health

\section{Research Questions}

How does the late night usage of smartphone impact the sleep quality of undergraduates? What are the effects of the late night usage of smartphones to their mental health?

\section{Significance of the Study}

This study will benefit anyone who wishes for their children or learners to use the smartphone as the main gadget to communicate as well as acquire knowledge. Most students have smartphones that allow them to access various websites at wee hours at their own convenience. The users can use their phones to adapt to the everchanging technology and learn new things daily. However, they need to use them wisely to enjoy the optimal benefits without endangering their physical and psychological health.

\section{Methodology}

This study employed a quantitative research design. Upon respondents' consent, the questionnaire via Google form was sent to 150 undergraduates from various higher learning institutions in Malaysia. However, only 106 responded. The questionnaire was adapted from Ganasegeran, et al. (2017). The. questionnaire consists of three sections. Section A relates to respondents' demographic profile, Section B consists of 10 items retrieving information related to students' use of the smartphone and their sleep time while Section C consists of 10 items investigating the link between sleep quality and the use of smartphones. 


\section{Conceptual Framework}

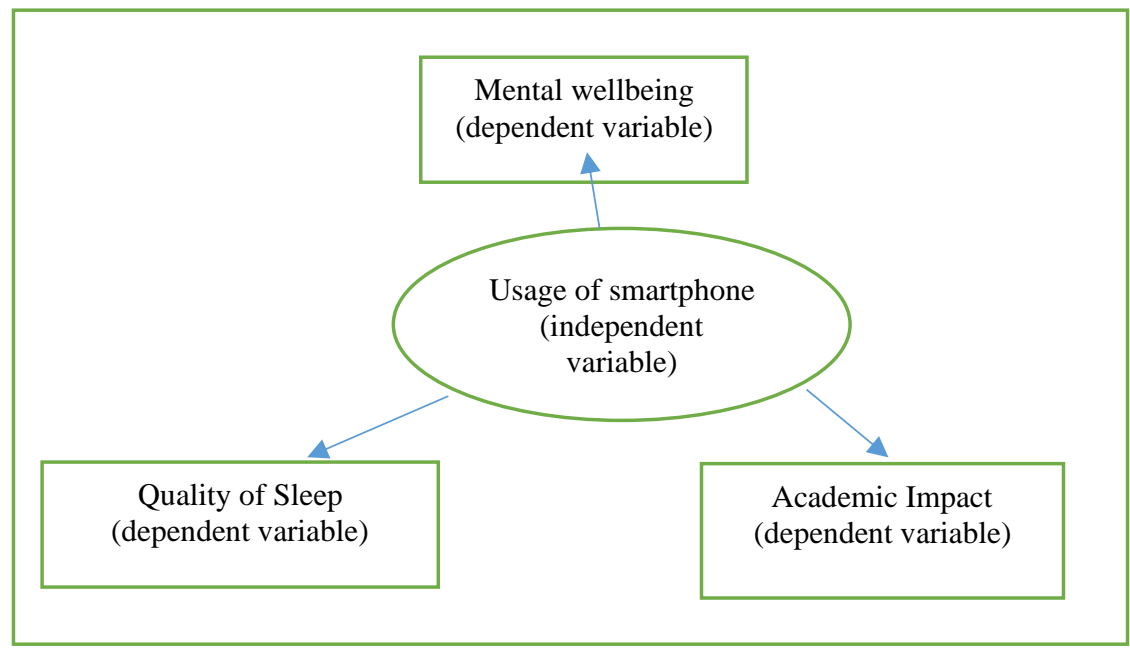

This study adopts the theory of mobile learning by Sharples, Taylor and Vavoula (2005) which anchors on the role of mobility and communication in learning environments. This theory states the possible advantages and disadvantages of using smartphones.

\section{Results and Discussion}

\section{Demographic profile}

In this study, $67.9 \%$ of the respondents were female and $32.1 \%$ were males. The highest respondents (48.1\%) were 21 years old followed by 19 (28.3\%), $22(11.3 \%)$ and 23 years old (5.7). The lowest respondents were in the category of 24 years old $(0.9 \%)$.

\section{Research question 1}

How does late night usage of the smartphone impact the sleep quality of undergraduates?

Table 1. Hours Spent on Smart Phone Usage

\begin{tabular}{|l|l|l|l|l|l|}
\hline \multicolumn{2}{|l|}{ Time Spent on Smart Phone Use After 10p.m } \\
\hline \multirow{2}{*}{} & Frequency & Per cent & $\begin{array}{l}\text { Valid pent } \\
\text { cent }\end{array}$ & $\begin{array}{l}\text { Cumulativ } \\
\text { e per cent }\end{array}$ \\
\hline Valid & $\begin{array}{l}\text { Less than an } \\
\text { hour }\end{array}$ & 7 & 6.6 & $\mathbf{6 . 6}$ & 6.6 \\
\cline { 2 - 7 } & An hour & 11 & 10.4 & $\mathbf{1 0 . 4}$ & 17.0 \\
\cline { 2 - 7 } & Two hours & 32 & 30.2 & $\mathbf{3 0 . 2}$ & 47.2 \\
\cline { 2 - 7 } & Three hours & 56 & 52.8 & $\mathbf{5 2 . 8}$ & 100.0 \\
\cline { 2 - 7 } & Total & $\mathbf{1 0 6}$ & $\mathbf{1 0 0 . 0}$ & $\mathbf{1 0 0 . 0}$ & \\
\hline
\end{tabular}

Table 1 shows the duration spent on their smartphones by students after 10p.m in hours. Most of the respondents from higher learning institutions spent three hours $(52.8 \%)$ on their smartphones, followed by two hours (30.2\%) and a lower number of students spent just an hour (10.4\%). Lastly, only $6.6 \%$ of the students used their smartphone for less than an hour after 10 p.m. This denotes that most students in higher learning institutions use their smartphone for three hours after 10p.m, which means they probably go to bed after 1a.m. This concurs with 
Wilmer et al. (2017) and Babak (2016) claim that college students use their smartphones at least five hours a day, which reduces their sleeping time. This also shows that the activity of using smartphone after 10p.m affects the students' sleep quality.

University students tend to actively use their mobile phones before falling asleep, which will inadvertently delay their sleeping time as highlighted in the Table 2, where most of them admit to being on their phones for 3 hours and more before falling asleep. This finding is supported by Nath and Mukherjee (2015), who pointed out that using a smart phone or a tablet at bedtime may strongly interfere with sleeping time because of the type of light which enters from the mobile device screen that affects the sleep-cycle adversely. In addition, most of them use their smartphones for entertainment purposes such as being on social media such as Twitter, and this is supported by White and Mills (2012) who found in their study that students were increasingly adopting smartphones with the focus on personal use rather than on acquiring new knowledge.

Table 2. Respondents' State of Physical in The Morning

\begin{tabular}{|c|c|c|c|c|c|}
\hline \multicolumn{5}{|c|}{ Respondents' State in The } \\
Morning \\
\hline \multirow{2}{|c|}{} & Frequency & Per cent & $\begin{array}{c}\text { Valid } \\
\text { Per cent }\end{array}$ & $\begin{array}{c}\text { Cumulative } \\
\text { Per cent }\end{array}$ \\
\hline \multirow{3}{*}{ Valid } & Sleepy & 40 & 37.7 & 37.7 & 37.7 \\
\cline { 2 - 6 } & Sluggish & 30 & 28.3 & 28.3 & 66.0 \\
\cline { 2 - 6 } & Fresh & 26 & 24.5 & 24.5 & 90.6 \\
\cline { 2 - 6 } & Irritated & 10 & 9.4 & 9.4 & 100.0 \\
\cline { 2 - 6 } & Total & $\mathbf{1 0 6}$ & $\mathbf{1 0 0 . 0}$ & $\mathbf{1 0 0 . 0}$ & \\
\hline
\end{tabular}

Table 2 shows, most of the students feel sleepy with the valid percentage of $37.7 \%$, followed by $28.3 \%$ of the students, who feels sluggish when they wake up in the morning. Although $24.5 \%$ of the students admitted to feeling very fresh in the morning after a good quality of sleep, $9.4 \%$ agreed that they woke up in the morning feeling irritable. This means that most of the student felt very sleepy when they woke up in the morning, which may be one of the symptoms of sleep deprivation. Feeling tired most of the time is one of the biggest symptoms of having sleeping deprivation (FNP, 2018). Nasirudeen et al. (2017) also emphasised that poor sleep quality leads to excessive sleepiness during the day and those who fall into this category do not feel their best to be continuously productive throughout the day. He added that a few would tend to feel irritated with certain things that bother them during the day and this could lead to stress and excessive worrying.

Table 3 shows that $15.38 \%$ out of 100 respondents are often wake up in the middle of the night. This may be due to insomnia and this is supported by Chu et al, (2018) that trouble falling asleep or waking up frequently during the night or early in the morning is a major symptom of insomnia . On the other hand, only $6.89 \%$ of the respondents are not awake during the night. In addition, $31.42 \%$ of the students agree that they sometimes wake up from their sleep in the middle of the 
night. Tao et al.(2017) and Nasirudeen et al. (2017) strongly felt that regularly waking up in the middle of the night to respond messages would lead to insomnia .

Table 3: Respondents' Response to Frequency in Waking Up in the Middle of the Night

\begin{tabular}{|l|l|}
\hline Frequency & Per cent (\%) \\
\hline Never & $6.89 \%$ \\
\hline Often & $15.38 \%$ \\
\hline Sometimes & $31.42 \%$ \\
\hline Rarely & $40.67 \%$ \\
\hline
\end{tabular}

The results also explain that less quality sleep time does affect the respondents' state in the morning. For example, they will become sleepy during morning classes as they their body and brain do not get enough rest throughout the day. As stated by Tao, et al. (2017), low quality of sleep, which leads to excessive sleepiness during the day leads to less productive activities in the day. Using the smartphone to access social networking sites such as Instagram and Twitter forces the undergraduates to sleep very late, making them unenergetic the following day. However, it is reverse to the respondents who sleep early as they only use their smartphone for not more than half an hour before going to sleep after 10 p.m. As supported by Tao, et al. (2017) which stated that regularly waking up for at least 20 to 30 minutes at night might be a sign that the individual may have insomnia. Based on the results, as they get enough sleep throughout the night, they never wake up in the middle of the night. This is because the brain has gained enough oxygen and fully recovered to face activities on the next morning as they will also stay fresh for the morning classes (Elhai, et al 2016).

\section{Research Question 2}

What are the effects of the late night usage of smart phone to their mental health?

Boumosleh and Jaalouk (2017) not only proposed that depression and anxiety were a positive predictor of smartphone addiction but also disclosed depression scores were a more powerful predictor as compared to anxiety. They also shared that there are symptoms of depression among intensive use of smartphones among teenagers. 
INTERNATIONAL JOURNAL OF ACADEMIC RESEARCH IN PROGRESSIVE EDUCATION AND DEVELOPMENT

Vol. 9, No. 3, 2020, E-ISSN: 2226-6348 @ 2020 HRMARS

Table 4. The Effects of Late Night Usage of the Smart Phone To The Mental Health

\begin{tabular}{|c|l|c|c|c|}
\hline No. & \multicolumn{1}{|c|}{ Statement } & $\begin{array}{c}\text { Disagree } \\
\text { (\%) }\end{array}$ & $\begin{array}{c}\text { Unsure } \\
\text { (\%) }\end{array}$ & $\begin{array}{c}\text { Agree } \\
\text { (\%) }\end{array}$ \\
\hline 1 & $\begin{array}{l}\text { I am able to concentrate during my lectures } \\
\text { the following day }\end{array}$ & 50.9 & 4.7 & 44.4 \\
\hline 2 & I feel sleepy during my lectures & 12.2 & 8.6 & 79.2 \\
\hline 3 & $\begin{array}{l}\text { I lack interest in participating in my lectures } \\
\text { and class activities }\end{array}$ & 42.5 & 7.7 & 49.8 \\
\hline 4 & $\begin{array}{l}\text { I regret sacrificing my sleeping time by } \\
\text { spending more time on my smartphone }\end{array}$ & 23.6 & 3.0 & 73.4 \\
\hline 5 & $\begin{array}{l}\text { I easily get stressed whenever any problem } \\
\text { occurs }\end{array}$ & 21.7 & 2.5 & 75.8 \\
\hline 6 & $\begin{array}{l}\text { I am able to think rationally whenever any } \\
\text { problem occurs }\end{array}$ & 53.8 & 4.7 & 41.5 \\
\hline 7 & $\begin{array}{l}\text { I am able to handle the pressure from my } \\
\text { problems }\end{array}$ & 75.8 & 2.5 & 21.7 \\
\hline 8 & $\begin{array}{l}\text { I feel anxious when I do not have my } \\
\text { smartphone with me }\end{array}$ & 9.4 & 8.6 & 82 \\
\hline 9 & $\begin{array}{l}\text { I have insecurities when I do not have my } \\
\text { smartphone with me }\end{array}$ & 19.3 & 5.8 & 74.9 \\
\hline 10 & $\begin{array}{l}\text { I lack confidence if I do not have my } \\
\text { smartphone with me }\end{array}$ & 8.5 & 62.5 & 32.2 \\
\hline 11 & $\begin{array}{l}\text { I have low self-esteem if I do not have my } \\
\text { smartphone with me }\end{array}$ & 27.4 & 32.2 \\
\hline
\end{tabular}

Table 4 shows that most of the undergraduates (50.9\%) disagreed with the statement that they can concentrate during on classes the next day. Majority also admit to being sleepy in class due to excessive time on their smartphones the night before (79.2\%) This would also affect their ability to concentrate in their lesson. These results are in line Wilmer et al. (2017) who claimed that students who use smartphone for about 4 to 10 hours will have challenges in concentrating on their classes on the next day.

Asked if they lack interest in participating in their class activities, 49.8\% agreed that late night usage of smart phone make them disinterested in participating in them. Also $73.4 \%$ of the respondent's regret sacrificing their sleeping time to spend more time on their smart phones. Sarhandi et al, (2017) in their studies found out that too much time spent on smartphones can distract students' focus on real life, their classroom engagement.

$75.8 \%$ of the respondents revealed that they get easily stressed whenever any problem occurs. The majority, $53.8 \%$ of the respondents disagreed that they are able to think rationally whenever any problem occurs. Sadly, $75.8 \%$ disagreed with the statement that they are able to handle the pressure from their problems. Gutiérrez et al. (2016) informed that smartphone addiction is detrimental both physically and psychologically. This causes learners to be stressed and 
pressurized over small matters and their state of thinking rationally. Acharya et al. (2013) too opined the same, where addiction or too much of smartphone usage affects students' health. The majority, $82 \%$ of the respondents agreed that they are anxious if their smartphone is not with them at all times. $74.9 \%$ shared that they have insecurities, $72.5 \%$ lack confidence and $70.5 \%$ have low self-esteem when their smartphone is not with them. This implies their strong addiction to smartphones. This is consistent with Shoukat (2019) who discovered that too much of smartphone usage is linked with psychological implications among students. Arefin et al. (2017) too claimed that increased dependency on the smartphone increased negative emotions among its users such as impatience and irritancies, as well as affected the academic performance of students.

In short, results show that students are addicted to their smart phones and rely too much on their gadgets. They also display poor concentration in class work and are often physically tired due to lack of sleep. Research shows that a chronic lack of sleep, or getting poor quality sleep, increases the risk of disorders including high blood pressure, cardiovascular disease, diabetes, depression, and obesity (National Institute of Neurological Disorders and Stroke, 2018).

\section{Conclusion}

No doubt smart phones can be a useful tool in many areas, like collecting information and disseminating information and empowering students to learn from anywhere they prefer. On another point, while bringing distant people closer together virtually, smartphones can also make people more distant by depending too much on it rather than interacting face-to-face with people around. Although there is not much research evidence exposing the impact of smartphones on the users' psychological well-being, Elhai, et al. (2016) advocated that excessive smartphone use leads to adverse mental health outcomes such as depression and anxiety. The current study presents evidence linking excessive smartphone usage to having negative effects on students'well-being. This is exhibited in students' responses which indicated their inability to concentrate the next day, being sleepy in class due to excessive time on their smartphones the night before as well as inability in facing the pressure and inability to think rationally whenever a problem occurs. Furthermore, undue use of smart phones often causes sleep disturbance affecting user's mental well-being. Thomée et al, (2011) as well as Thomée, et al (2007) too indicated that smartphones deprive people's sleep.

The study also considers several items on different aspects of self-audit and reflection such as feeling insecure without their smartphones, affecting their level of confidence, which explain their dependency on their smartphones. Previous research findings too indicate that smartphone use could impede some of these facets of human functioning. Rotondi et al. (2017) disclosed that smartphone use can lead to reduced face-to-face interaction. Research (Ayar, et al, 2018; Yildirim \& Correia, 2015) users especially university students have a high ratio of anxieties or feeling of discomfort of being temporarily without their smartphones. They perceive this emotion to be outcomes of excessive use of smartphones. At times, individuals resort to excessive smartphone use as a coping strategy to deal with negative emotions like depression and anxiety (Elhai et al, 2016; Kim et al. 2015). 
In conclusion, this study has provided some insights into the negative association of excessive smartphone use with the psychological well-being among university students in Malaysia. Although we cannot totally blame smartphone as the only cause of poor mental or physiological health issues in adolescents, it is obvious that university students' physical and psychological well-being is associated with smartphone addiction. We cannot ignore this unhealthy relationship and its adverse effects on adolescents. To reduce their harmful effects, students should always remember that the mobile phone is a friend, not a master, and it should never be used excessively. It is suggested that more studies be done in this regard to further investigate the effects of smartphone usage on young people.

\section{Implications of the Study}

The current study contributes to the overall understanding of the relationship between the wellbeing of learners and smartphone usage. By obtaining feedback from respondents, it provides a comprehensive mapping between the use of smartphones and quality of sleep and mental wellbeing of the younger generation. In cases where there is excessive use of the smartphone, addiction to the smartphone may occur as it becomes the main medium of communication. This aspect also causes psychological problems, as people start to feel uncomfortable in face-to-face communication. These findings contribute to the field of knowledge especially to the literature by anchoring the relationship between smartphone usage and quality of sleep. If this problem is not taken seriously, these individuals may develop psychological challenges as postulated by Augner and Hacker (2017) and Ayar, et al. (2018).

Furthermore, the research furthers our understanding of the challenges of smartphone usage affecting students' academic performance. Targeting smartphone usage as a modifiable behaviour may be a relatively straightforward means to helping students to improve their overall wellbeing.

\section{Recommendations}

More research is needed to corroborate our findings, though the results from this study suggest that there is a critical need to promote healthy ways of smartphone usage, as well as the need for parents and educators in finding healthy ways to promote the psychological well-being of young people.

It is also suggested that more studies be conducted to clarify the dependency and effects of the smartphone on young users Besides, future research needs to study how users can utilise smartphones without much health impairment to the users. Parents, educators and students need to know the effects of mobile phone and also need to increase their knowledge on safe use of Internet by students. Being less dependent on the device and restricting the time spent on it, are some of the practical measures to be considered.

\section{References}

Acharya, J. A., Acharya, I., \& Waghrey, D. (2013). A study on some psychological health effects of cell-phone usage amongst college going students. International Journal of Medical Research \& Health Sciences, 2(3): 388-394. 
INTERNATIONAL JOURNAL OF ACADEMIC RESEARCH IN PROGRESSIVE EDUCATION AND

DEVELOPMENT

Vol. 9, No. 3, 2020, E-ISSN: $2226-6348 @ 2020$ HRMARS

Akpan, K. P., \& Abe, E. (2017). Effectiveness of WhatsApp as a collaborative tool for learning among undergraduate students in University of Uyo, Akwa Ibom state. International Journal of Advanced Education and Research, 2(5), 43-46.

Alavi, S. S., Ferdosi, M., Jannatifard, F., Eslami, M, Alaghemandan, H., Setare, M. (2012). Behavioral addiction versus substance addiction: correspondence of psychiatric and psychological views. Int J Prev Med. 3:290-294.

Arefin, S., Islam, R., Mustafi, M. A. A., Afrin, S., Islam, N. (2017). Impact of smartphone addiction on business students' academic performance: a case study. Independ J Manage Prod. 8:955-975.

Arumugam, N., Ismail, N., Selvanayagam, S., \& Sathiyasenan, S. D. (2019). Social Media In Enhancing English Language Competence Among Undergraduates. Journal of Institutional Research South East Asia, 17 (2), p. 86 - 102. ISSN 1675-6061. doi:10.1002/j.15566676.1996. tb02311.x

Augner, C., Hacker, G. W. (2017). Associations between problematic mobile phone use and psychological parameters in young adults. Int J Public Health. 57:437-444.

Ayar, D., Gerceker, O. G., Ozdemir, E. Z., \& Bektas, M. (2018). The Effect of Problematic Internet Use, Social Appearance Anxiety, and Social Media Use on Nursing Students' Nomophobia Levels. Computers, informatics, nursing: CIN. Epub 2018/07/14. 10.1097/cin.0000000000000458

Boumosleh, J. M., Jaalouk, D. (2017). Depression, anxiety, and smartphone addiction in university students- a cross-sectional study. PLos ONE.12(8):e0182239

Cha, S. S., Seo, B. K. (2018). Smartphone use and smartphone addiction in middle school students in Korea: prevalence, social networking service, and game use. Health Psychology Open.15.

Chu, H. C., Liu, Y. M., \& Kuo, F. R. (2018). A mobile sleep-management learning system for improving students' sleeping habits by integrating a self-regulated learning strategy: randomized controlled trial JMIR Mhealth Uhealth. 6(10): e11557

Davis, K. (2018), What's to know about sleep deprivation? https://www.medicalnewstoday.com/articles/307334.php

Elhai, J. D., Dvorak, R. D., Levine, J. C., Hall, B. J. (2016). Problematic smartphone use: A conceptual overview and systematic review of relations with anxiety and depression psychopathology. Journal of affective disorders, 207:251-9.10.1016/j.jad.2016.08.030

FNP, K. D. (2018). Medical New Today. What's to know about sleep deprivation? https://www.medicalnewstoday.com/articles/307334.php

Ganasegeran, K., Renganathan, P. \& Rashid A. (2017). The m-Health revolution: Exploring perceived benefits of WhatsApp use in clinical practice. International, Journal Med Inform, 97:145-151.

Giri, P., Baviskar, M. \& Phalke, D. (2013). Study of sleep habits and sleep problems among medical students of Pravara Institute of Medical Sciences Loni, Western Maharashtra, India, Annals of Medical and Health Sciences Research, 3(1), 51-54.

Gutiérrez, J., Rodríguez, F., Rubio, G. (2016) Cell-phone addiction: a review. Front Psychiatry, 7:175. 
Jafarzadeh-Kenarsari, F., Pourghane, P., \& Mahdavi, N. (2018). Consequences of using smartphone technology in university students: Experiencing challenges. J Qual Res Health Sci 7(3): 252-63.

Kim, J. H., Seo, M., \& David, P. (2015). Alleviating depression only to become problematic mobile phone users: Can face-to-face communication be the antidote? Computers in Human Behavior, 51:440-447. 10.1016/j.chb.2015.05.030

Lenord, J. (2015). 16 seriously damaging side effects of your smartphone addiction.https://www.naturallivingideas.com/16-seriously-damaging-side-effects-ofyour- smartphone-addiction/

Lepp, A., Barkley, J. E., \& Karpinski, A.C. (2015): The relationship between cell phone use and academic performance in a sample of U.S. college students. SAGE Open, 5: 1-9.

Malaysian Healthcare Performance (2017). Technical Report 2016, Unit National Institute of Health, Ministry of Health, Malaysia. https://www.moh.gov.my/moh/resources/Penerbitan/Laporan/Umum/Mental\%20Health care\% 20Performance\%20Report\%202016.pdf

Miller, Y. A. (2017). Smartphones negative effects: A summary of latest comprehensive research. https://www.aish.com/ci/s/Smartphones-Negative-Effects-A-Summary-of-Latest-

Comprehensive-Research.html

Ministry of Health Malaysia. (2016). Patient Congestion: Sharing experience with the implementation of Lean at Tengku Ampuan Rahimah Hospital Klang, Malaysia. http://www.mpc.gov.my/wp-content/uploads/2016/04/Hospital-Tengku-Ampuan-.pdf

Nath, D. A., \& Mukherjee, S. (2015). Impact of mobile phone/smartphone: A pilot study on positive and negative effects . International Journal of Advance Research In Computer Science And Management Studies, 295-297.

National Institute of Neurological Disorders and Stroke. (2018). Brain basics: Understanding sleep.https://www.ninds.nih.gov/Disorders/Patient-Caregiver-

Education/Understanding-Sleep

Parasuraman, S. Sam, A.T., Yee, S.W., Chuon, B.L. \& Ren, L.Y.(2017) Smartphone usage and increased risk of mobile phone addiction: A concurrent study. Int J Pharma Investig, 7:125-131.

Rotondi, V., Stanca, L., \& Tomasuolo, M. (2017). Connecting alone: Smartphone use, quality of social interactions and well-being. Journal of Economic Psychology, 63: 17-26. 10.1016/j.joep.2017.09.001

Russell, D. (2018). Mobile phones in the classroom. https://www.teachermagazine.com.au/articles/mobile-phones-in-the-classroom-whatdoes-the-research-say

Sarhandi, P. S., Bajnaid, A., \& Elyas, T. (2017). Impact of smartphone-based activities on EFL students' engagement. English Language Teaching, 10(6) :103-117.

Sharples, M. T., \& Vavoula, G. (2006). A Theory of Learning for the Mobile Age. Andrews, R. and Haythornthwaite, C. The Sage Handbook of Elearning Research, Sage publications, pp.221-247, 2006. ffhal-00190276f

Short, M. A., \& Louca, M. (2015). Sleep deprivation leads to mood deficits in healthy adolescents. Sleep Medicine, 16(8):987-993. pmid:26141007 
INTERNATIONAL JOURNAL OF ACADEMIC RESEARCH IN PROGRESSIVE EDUCATION AND

DEVELOPMENT

Vol. 9, No. 3, 2020, E-ISSN: 2226-6348 @ 2020 HRMARS

Shoukat, S. (2019). Cell phone addiction and psychological and physiological health in adolescents. EXCLI journal, 18: 47-50.PMCID: PMC6449671

Tao, S., Wu, X., Zhang, Y., Zhang, S., Tong, S., \& Tao, F. (2017).Effects of sleep quality on the association between problematic mobile phone use and mental health symptoms in Chinese college students. Int J Environ Res Public Health, 14(2):185. doi: 10.3390/ijerph14020185 Chu HC.

Tariq, R. S. (2013). Impact of smartphones on society. https://pdfs.semanticscholar.org/2c28/0b6a690442a97a571e09b2404e2d21720db4.pdf

Thomée, S., Härenstam, A., \& Hagberg, M. (2011). Mobile phone use and stress, sleep disturbances, and symptoms of depression among young adults-a prospective cohort study. BMC Public Health, 11(1):66 10.1186/1471-2458-11-66

Thomée, S., Eklöf, M., Gustafsson, E., Nilsson, R., \& Hagberg, M. (2007). Prevalence of perceived stress, symptoms of depression and sleep disturbances in relation to information and communication technology (ICT) use among young adults-an explorative prospective study. Computers in Human Behavior, 23(3):1300-1321. 10.1016/j.chb.2004.12.007

Yildirim, C., \& Correia, A. P. (2015). Exploring the dimensions of nomophobia: Development and validation of a self-reported questionnaire. Computers in Human Behavior, 49:130-137. 10.1016/j.chb.2015.02.059.

Wilmer, H., Sherman, L. E., \& Chein, J. M. (2017). Smartphones and Cognition: A Review of Research Exploring the Links between Mobile Technology Habits and Cognitive Functioning. Frontiers in Psychology, 8: 605.

White, J., \& Mills, D. J. (2012). Get smart!: Smartphones in the Japanese classroom. In A. Stewart, \& N. Sonda, JALT2011 Conference Proceedings, Tokyo, 328-337. 